\title{
Estimation of the contribution of exports to the provincial economy: an analysis based on China's multi-regional input-output tables
}

\author{
Sanmang $\mathrm{Wu}^{1,2^{*}}$, Shantong $\mathrm{Li}^{3}$ and Yalin Lei $\mathrm{i}^{1,2}$
}

${ }^{*}$ Correspondence:

wusanmang@sina.com

${ }^{1}$ School of Humanities

and Economic Management,

China University

of Geosciences, No. 29

Xueyuan Road, Haidian

District, Beijing 100083

People's Republic of China

Full list of author information

is available at the end of the article

\begin{abstract}
This paper developed an estimation model for the contribution of exports to a country's regional economy based on the Chenery-Moses model and conducted an empirical analysis using China's multi-regional input-output tables for 1997, 2002, and 2007. The results indicated that China's national exports make significantly different contributions to the provincial economy in various regions, with the greatest contribution being observed in the eastern region and the smallest in the central region. The provinces are also subjected to significantly different export spillover effects. The boosting effect for the eastern provinces is primarily generated from local exports, whereas the western provinces primarily benefit from the export spillover effect from the eastern provinces. The eastern provinces, such as Guangdong, Zhejiang, Jiangsu, and Shanghai, are the primary sources of export spillover effects, and Guangdong is the largest source of export spillover effects for almost all of the provinces in China.
\end{abstract}

Keywords: Contribution of exports, Multi-regional input-output tables, Spillover effect

\section{Background}

Foreign trade has played an important role in China's rapid economic growth. This trade provides a broad and enormous market for China's economy and accelerates China's entry into the global division of labor and industrial system while simultaneously bringing capital, advanced technologies, and management experience to China's economy, improving the efficiency of domestic resource utilization and configuration, and enhancing China's international competitiveness. Especially after joining the World Trade Organization, China's economy has gradually become more closely and profoundly integrated into the global economy. China's total imports and exports reached $\$ 3.86676$ trillion in 2012, which are 6.6 times China's total imports and exports in 2001. China has surpassed Britain, France, Japan, and Germany to become the world's second largest trading power after the United States.

Because of the increasingly important role of foreign trade, China's economy is becoming increasingly closely connected with the global economy and is therefore more strongly affected by the global economy. The interaction between China's economy and the global economy since the international financial crisis in 2008 is the best evidence

(c) 2016 Wu et al. This article is distributed under the terms of the Creative Commons Attribution 4.0 International License (http:// creativecommons.org/licenses/by/4.0/), which permits unrestricted use, distribution, and reproduction in any medium, provided you give appropriate credit to the original author(s) and the source, provide a link to the Creative Commons license, and indicate if changes were made. 
for this connection. In the last two or three years, however, the sustained global economic downturn led to a strong economic decline in China. ${ }^{1}$ Therefore, an analysis of the contribution of exports to China's economy has become an important area of research, and boosting China's economy by promoting exports has become a concern for policymakers.

Unlike many other countries, China has vast territory with notably different geographical conditions and natural endowments across regions. As a result, each region's participation in the national division of labor and position in the global industry chain is markedly different. Thus, changes in the global market have different impacts on China's regional economy. The trade data show that nearly $90 \%$ of China's imports and exports occur in the ten provinces in the eastern region, but it is unclear whether this means that changes in the global market only affect the economies of the eastern provinces. This requires further analysis in the context of the constant integration of the domestic market. In short, properly understanding and estimating the contribution of exports to China's regional economy is crucial for policymaking by both local and central governments.

The objective of the paper is to estimate the contribution of exports to the provincial economy in China. The used method of the paper is the measurement model for the contribution of exports to the regional economies of a country based on the Chenery-Moses model. This paper conducted an empirical analysis using the China's multiregional input-output tables for 1997, 2002, and 2007. The findings in the paper are as flowing:

First, national exports make significantly different contributions to provincial GDP in different regions in China.

Second, each province has a different source of contribution made by exports.

Third, Guangdong, Zhejiang, Jiangsu and Shanghai in the eastern region were the main source of export spillover effects for other provinces in China.

\section{Literature review}

According to the existing literature, there are four primary types of quantitative research on the contribution of exports to the economy.

The first type uses direct foreign trade dependence [i.e., using exports as a percentage of Gross Domestic Product (GDP) to reflect the contribution of exports to the economy]. ${ }^{2}$ Although this method is intuitive, it does not consider inherent economic linkages and cannot measure the contribution of exports to GDP.

The second type of quantitative research uses the national income identity to decompose GDP into consumption, investment and net exports using an elasticity formula to measure the contribution of net exports to economic growth. Typical examples of this type of research include studies by Chen et al. (2004). This method cannot be used to measure the contribution of exports. After comparing GDP data with net exports in previous years, Zhang and $\mathrm{Hu}$ (1999) determined that "net exports have 'a negative correlation' with GDP growth," which also indicates that this method underestimates or mistakenly reflects the contribution of foreign trade.

\footnotetext{
1 The causes of China's economic decline also include the internal factor of the transition phase.

2 Many studies on the measurement of foreign trade dependence mainly focus on the choice of the denominator indicator in the dependence calculation equation (GDP or final output) and the calculation standard (price or PPP).
} 
The third type uses the econometrics regression model to analyze the contribution of exports to economic growth. Ghirmay's (2001) study used time-series data from 15 lowincome developing countries and a vector error correction model to examine the relationships among exports, investment and economic growth. Islam (1998) used a VEM model to study the relationship between export expansion and economic growth in 15 Southeast Asian countries. This method requires using time series data over a long period, so it is more suitable for mature economies in which exports make a stable contribution to economic growth. However, for a county with rapid foreign trade growth and a changing structure, such as China, this method cannot accurately measure the contribution of exports.

The fourth type of quantitative research uses input-output tables to measure the contribution of exports to the economy. The input-output model is a tool for analyzing the interdependence and mutual economic and technical constraints of various sectors of the national economy in the production process. This method uses the input-output identity and inputoutput multiplier model to measure the direct and indirect contributions of exports to the economy. The contribution takes place after the exports have a cyclic cumulative effect on the economy through the relationships among various production sectors of the national economy. Shen and Wu (2004) developed a method that uses input-output tables to measure the contribution of exports to the formation and growth of GDP. This method calculated and analyzed the contribution of each sector's exports to China's GDP growth and analyzed and revealed the reasons for the declining contribution rate of unit exports from 1997 to 2001. Many similar studies have been conducted, including those by Mattoo et al. (2013), Shen (2011) and Koopman et al. (Koopman et al. 2014). Compared with the first three quantitative analysis methods, this fourth method has the advantage of using a multiplier principle to satisfy the relationships among the national economic accounts and takes full account of the impact of economic structures. The input-output method thus measures both the macroeconomic effects and sector impacts. The disadvantage of this method is that it carries higher data requirements and requires the use of input-output tables.

Based on a comprehensive comparison of these four methods, we determined that the fourth method is the most suitable for measuring the contribution of China's exports to the economy, especially the export contribution in a given year. However, it has not been found that the use of Multi-Regional Input-Output (MRIO) model to study the contribution of exports to a country's regional economy. Wu et al. (2015) used the Single-Regional Input-Output (SRIO) model to measure the contributions of the four components of gross domestic product in various regions in China. The four components are consumption, international exports, inter-provincial and investment. The SingleRegional Input-Output model reflects the interaction between foreign trade and the internal economy, but it does not reflect the economic relations among different regions of the country. That means it does not reflect the spillover and feedback between the foreign trades in the different regions. Therefore, although the Single-Regional Input-Output model can estimate the direct contribution of the export to local economy. It is not able to estimate the indirect contribution of the exports to regional economy. For example, the Single-Regional Input-Output model can estimate the direct contribution of the export of a region to a region economy, but it cannot estimate the indirect contribution of the export of A region to B region economy. In addition, although many scholars have carried out analysis using Multi-Regional Input-Output (MRIO) models, these studies 
only focus on the measurement of economic relationships between regions instead of the contribution of exports to a regional economy. For example, Pan and Li (2007) also used IRIO tables and found that the spillover effect of a coastal area's economic development on the inland area was not significant. In fact, it was even less significant than the inland area's spillover effect on the coastal area. Many similar studies have been conducted, including studies by Shan and Wilson (2001) and Liu et al. (2012).

The existing literature shows that to measure the contribution of national exports to a regional economy more accurately, data and a model of interregional trade linkages are required. The MRIO model contains the inter-industrial linkages both within a region and between regions, so it can be applied to analyzing the contribution of exports to regional economy. Therefore, this study used the fourth method to develop China's MRIO model, which was used to measure the contributions of national and regional exports to the regional economy.

\section{Multi-regional input-output model and data Multi-regional input-output model}

In light of the theories of the input-output model, the IRIO tables/models proposed by Isard (1951) are an ideal tool for analyzing interregional economic linkages. These tables contain not only the economic linkages within a region but also detailed regional economic linkages. Input-output tables can clearly indicate the origins of goods in each region. In reality, however, it is difficult to collect such detailed trade data, especially trade coefficients. Therefore, few studies use the IRIO model proposed by Isard. To overcome the difficulties associated with data collection, Chenery (1953) and Moses (1955) proposed the MRIO model, which is also called the Chenery-Moses model or column coefficient model. This model assumes that different goods (intermediate inputs, final consumption, and investment in different sectors) in each region come from the same source. ${ }^{3}$ Therefore, only the interregional trade data are required to obtain the production and consumption locations of the tradable goods (instead of the sectors using them), whether for investment or final consumption. This greatly reduces the quantity of data needed, so this study used the MRIO model proposed by Chenery and Moses. ${ }^{4}$

Suppose that a country has $n$ regions and $m$ production sectors, and each industry only produces one product. The total demand for the product of sector $i$ in region $r$ can be expressed by the following equation:

$$
\begin{aligned}
& x_{i}^{r}=\left(t_{i 1}^{r, 1}+t_{i 2}^{r, 1}+\cdots+t_{i, 12}^{r, 1}+t_{i, m}^{r, 1}+f_{i}^{r, 1}\right) \quad \text { Total demand of region } 1 \text { for product } \mathrm{i} \text { from region } \mathrm{r} \\
& +\left(t_{i 1}^{r, 2}+t_{i 2}^{r, 2}+\cdots+t_{i, 12}^{r, 2}+t_{i, m}^{r, 2}+f_{i}^{r, 2}\right) \quad \text { Total demand of region } 2 \text { for product } \mathrm{i} \text { from region } \mathrm{r} \\
& +\cdots \\
& +\left(t_{i 1}^{r, r}+t_{i 2}^{r, r}+\cdots+t_{i, 12}^{r, r}+t_{i, m}^{r, r}+f_{i}^{r, r}\right) \quad \text { Total demand of region } \mathrm{r} \text { for its own product } \mathrm{i} \\
& +\cdots \\
& +\left(t_{i 1}^{r, n}+t_{i 2}^{r, n}+\cdots+t_{i, 12}^{r, n}+t_{i, m}^{r, n}+f_{i}^{r, 30}\right) \text { Total demand of region } \mathrm{n} \text { for product } \mathrm{i} \text { from region } \mathrm{r} \\
& +e_{i}^{r} \quad \text { Export demand of product } \mathrm{i} \text { from region } \mathrm{r}
\end{aligned}
$$

\footnotetext{
${ }^{3}$ For example, in terms of the source, two-thirds of the coal consumed by Beijing is assumed to come from Shanxi and one-third is assumed to come from Hebei. In the IRIO model, the proportion of coal consumed from any given source by different sectors of Beijing may be different, but in the MRIO model, the proportion of coal consumed from any given source by different sectors of Beijing is the same as the assumption.

4 For a detailed description of the MRIO model, please refer to Chenery (1953) and Moses (1955).
} 
where $i$ and $j$ are the production sectors $(i, j=1, \ldots, \mathrm{m})$, and $r$ and $s$ denote region $(r$, $s=1, \ldots, \mathrm{n}) . x_{i}^{r}$ is the total demand/output of products by sector $i$ in region $r^{5} ; t_{i, j}^{r, s}$ is the intermediate input demand of sector $j$ in region $s$ for the product of sector $i$ in region $r$; $f_{i}^{r, s}$ is the domestic final demand (including final consumption and investment) of region $s$ for the products from sector $i$ in region $r$; and $e_{i}^{r}$ is the export demand for the products of sector $i$ in region $r$.

Equation 1 shows that a region's product demand not only includes the intermediate input demand and final demand within the region but also the intermediate input demand and final demand of other domestic regions for the products. There is also the region's export demand.

The most critical part of the regional input-output model is the O-D matrix of commodity flows (as shown in Table 1). The trade coefficients can be obtained through the O-D matrix (i.e., the composition of source areas of each product in each region and the composition of the destinations). Therefore, the MRIO model is used with the assumption that the products in the destination areas have the same source. The corresponding trade coefficients can be obtained by dividing the elements of the $\mathrm{O}-\mathrm{D}$ matrix by the total number of the rows. Therefore, to determine the total demand of region $r$ for product $i$, the proportion of this product provided by region $r$ can be calculated $\left(c_{i}^{r, r}\right)$, along with the proportion of the product provided by other regions $\left(c_{i}^{s, r}\right)$.

Through the regional input-output tables, the intermediate input technical coefficient of each region for the domestic products can be obtained $\left(a_{i j}^{r}\right)$. This coefficient reflects the input demand of region $r$ for various domestic products in producing every unit of product $j$, including the products from this region and from other domestic regions (Moses 1955). This effect can be expressed by the following equation:

$$
a_{i j}^{r}=\frac{t_{i j}^{\bullet, r}}{x_{j}^{r}}
$$

In the equation, the symbol $\bullet$ represents a summary of all the source areas. The trade coefficient and intermediate input coefficient are substituted into Eq. 1 to obtain the following equation:

Table 1 Flow matrix of product $i$ (O-D matrix)

\begin{tabular}{lllll}
\hline & & Destination & & \\
\cline { 3 - 5 } & & $\mathbf{1}$ & $\ldots$ & $\mathbf{n}$ \\
\hline Source & 1 & $z_{i}^{1,1}$ & $z_{i}^{1,5}$ & $z_{i}^{1,1}$ \\
& $\ldots$ & $\ldots$ & $\ldots$ & $\ldots$ \\
& $n$ & $z_{i}^{n, 1}$ & $z_{i}^{n, 5}$ & $z_{i}^{1, n}$ \\
& Total & $d_{i}^{1}$ & $d_{i}^{5}$ & $d_{i}^{n}$ \\
& $c_{i}^{r, r}=\frac{z_{i}^{r, r}}{d_{i}^{r}} c_{i}^{s, r}=\frac{z_{i}^{s, r}}{d_{i}^{r}}$ & & & \\
\hline
\end{tabular}

\footnotetext{
${ }^{5}$ Import demand has been deducted.
} 


$$
\begin{aligned}
x_{i}^{r}= & \left(c_{i}^{r, 1} a_{i 1}^{1} x_{i}^{1}+\cdots+c_{i}^{r, 1} a_{i, m}^{1} x_{i}^{1}+c_{i}^{r, 1} f_{i}^{\bullet 1}\right) \\
& +\cdots \\
& +\left(c_{i}^{r, n} a_{i 1}^{n} x_{i}^{n}+\cdots+c_{i}^{r, n} a_{i, 13}^{n} x_{i}^{n}+c_{i}^{r, n} f_{i}^{\bullet n}\right) \\
& +e_{i}^{r}
\end{aligned}
$$

where $i=1, \ldots, 13$. Equation 2 can be rewritten in the form of the matrix as follows:

$$
X=C A X+C F+E
$$

In the matrix, $\mathrm{X}$ is the output matrix; $\mathrm{C}$ is the trade coefficient matrix; $\mathrm{A}$ is the matrix of the domestic intermediate input coefficient; $\mathrm{F}$ is the final demand matrix; and $\mathrm{E}$ is the export matrix. The specific elements of each matrix are as follows:

$$
\mathrm{X}=\left[\begin{array}{c}
\mathrm{x}^{1} \\
x^{2} \\
\vdots \\
\mathrm{x}^{n}
\end{array}\right] \text {, where } \mathrm{x}^{r}=\left[\begin{array}{c}
x_{1}^{r} \\
x_{2}^{r} \\
\vdots \\
x_{m}^{r}
\end{array}\right]
$$

and $x_{i}^{r}$ is the total output of sector $i$ in region $r$.

$$
C=\left[\begin{array}{ccc}
c^{1,1} & \cdots & c^{1, n} \\
\cdots & \cdots & \cdots \\
c^{n, 1} & \cdots & c^{n, n}
\end{array}\right], \text { where } c^{r, s}=\left[\begin{array}{cccc}
c_{1}^{r, s} & 0 & 0 & 0 \\
0 & c_{2}^{r, s} & 0 & 0 \\
0 & 0 & \ddots & 0 \\
0 & 0 & 0 & c_{m}^{r, s}
\end{array}\right],
$$

and $c_{i}^{r, s}$ is the trade coefficient (i.e., the proportion of the products of sector $i$ in region $s$ flowing from region $r$ to the sector's products flowing from all regions to region $s$ ).

$$
A=\left[\begin{array}{cccc}
a^{1} & 0 & 0 & 0 \\
0 & a^{2} & 0 & 0 \\
0 & 0 & \ddots & 0 \\
0 & 0 & 0 & a^{n}
\end{array}\right] \text {, where } a^{r}=\left[\begin{array}{ccc}
a_{1,1}^{r} & \cdots & a_{1, m}^{r} \\
\cdots & \cdots & \cdots \\
a_{m, 1}^{r} & \cdots & a_{m, m}^{r}
\end{array}\right],
$$

and $a_{i, j}^{r}$ is the technical coefficient of the domestic intermediate input of sector $j$ in region $r$.

$$
\mathrm{F}=\left[\begin{array}{c}
\mathrm{f}^{1} \\
\mathrm{f}^{2} \\
\vdots \\
\mathrm{f}^{\mathrm{n}}
\end{array}\right], \text { where } \mathrm{f}^{r}=\left[\begin{array}{c}
f_{1}^{r} \\
f_{2}^{r} \\
\vdots \\
f_{\mathrm{m}}^{r}
\end{array}\right],
$$

and $f_{i}^{r}$ is the final consumption demand (including consumption demand and investment demand) for the products of sector $i$ in region $r$.

$$
\mathrm{E}=\left[\begin{array}{c}
\mathrm{e}^{1} \\
\mathrm{e}^{2} \\
\vdots \\
\mathrm{e}^{\mathrm{n}}
\end{array}\right], \text { where } \mathrm{e}^{r}=\left[\begin{array}{c}
e_{1}^{r} \\
e_{2}^{r} \\
\vdots \\
e_{\mathrm{m}}^{r}
\end{array}\right]
$$

and $e_{i}^{r}$ is the export demand for the products of sector $i$ in region $r$. 
Equation 3 can be further rewritten into Eq. 4:

$$
X=C A X+C F+E \Rightarrow(I-C A) X=C F+E \Rightarrow X=(I-C A)^{-1}(C F+E)
$$

Equation 4 can be used for simulation analysis, namely, the measurement of the contributions of various final demands (including domestic consumption, investment, and export) to total output. If the change in unit volume is used, the multiplier effect of various final demands can be calculated. The focus of this study is to measure the contributions of exports to a regional economy, so the export is separated from Eq. 4:

$$
X E=(I-C A)^{-1} E
$$

where $\mathrm{XE}$ is the total output contributed by the country's regional exports. The value added rate of each sector is then introduced:

$$
V A E=V(I-C A)^{-1} E
$$

where VAE is the contribution of the country's regional exports to the national value added value added, including direct and indirect contributions. The specific matrix elements are as follows:

$$
V=\left[\begin{array}{cccc}
v^{1} & 0 & 0 & 0 \\
0 & v^{2} & 0 & 0 \\
0 & 0 & \ddots & 0 \\
0 & 0 & 0 & v^{n}
\end{array}\right] \text {, where } v^{r}=\left[\begin{array}{cccc}
v_{1}^{r} & 0 & 0 & 0 \\
0 & v_{2}^{r} & 0 & 0 \\
0 & 0 & \ddots & 0 \\
0 & 0 & 0 & v_{m}^{r}
\end{array}\right],
$$

and $v_{\mathrm{i}}^{\mathrm{r}}$ is the value added rate of sector $i$ in region $r$.

$$
V A E=\left[\begin{array}{c}
v a e^{1} \\
v a e^{2} \\
\vdots \\
v a e^{n}
\end{array}\right] \text {, where } v a e^{r}=\left[\begin{array}{c}
v a e_{1}^{r} \\
v a e_{2}^{r} \\
\vdots \\
v a e_{m}^{r}
\end{array}\right],
$$

and vae ${ }_{\mathrm{i}}^{\mathrm{r}}$ is the value added of sector $i$ in region $r$ contributed by the country's regional exports.

The total national value added contributed by regional exports is

$$
\mathrm{VAE}=\sum_{r=1}^{\mathrm{n}} \mathrm{vae}^{r}
$$

The value added of region $r$ contributed by national exports is

$$
v a e^{r}=\sum_{i=1}^{\mathrm{m}} v a e_{i}^{r}
$$

However,

$$
\mathrm{VAE}=\sum_{r=1}^{\mathrm{n}} \sum_{i=1}^{\mathrm{m}} v a e_{i=1}^{r}
$$


That is, the value added contributed by national exports can be decomposed into the sum of the value added of different regions contributed by national exports. In addition, through further decomposition, the contribution of the exports of region $r$ to the national value added and to the value added of region $s$ can be obtained.

$$
V A E^{\bullet, r}=V(I-C A)^{-1} E^{r}
$$

$V A E^{\boldsymbol{\bullet}, r}$ is the contribution of region $r^{\prime}$ 's exports to the regional value added of the country. $E^{r}$ is the export matrix of region $r$. The forms of the matrix elements of $V A E^{\bullet, r}$ are as follows:

$$
V A E^{\bullet, r}=\left[\begin{array}{c}
\mathrm{vae}^{1, r} \\
\mathrm{vae}^{2, r} \\
\vdots \\
\operatorname{vae}^{\mathrm{n}, r}
\end{array}\right]
$$

$V A E^{\mathrm{s}, \mathrm{r}}$ is the value added of region $s$ contributed by the exports of region $r$. The forms of the matrix elements of vae ${ }^{\mathrm{s}, \mathrm{r}}$ are as follows:

$$
\mathrm{vae}^{\mathrm{s}, \mathrm{r}}=\left[\begin{array}{c}
v a e_{1}^{s, r} \\
v a e_{2}^{s, r} \\
\vdots \\
v a e_{\mathrm{m}}^{s, r}
\end{array}\right]
$$

$v a e_{i}^{e, r}$ is the value added of sector $i$ in region $s$ contributed by the exports of region $r$. Therefore, the total value added of region $s$ contributed by the exports of region $r$ is

$$
\mathrm{vae}^{\mathrm{s}, \mathrm{r}}=\sum_{i}^{\mathrm{m}} v a e_{i}^{s, r}
$$

Equation 13 can be used to calculate the direct and indirect contributions of exports to the value added of a particular region. When $r=s$, vae ${ }^{\mathrm{s}, \mathrm{s}}$ is the direct contribution of the exports of region $s$ to its value added; when $r \neq s, v^{s, r}$ is the indirect contribution of the exports of region $r$ to the value added of region $s$.

\section{Data}

The MRIO model was developed from the MRIO tables. The Development Research Center of the State Council of China cooperated with the National Bureau of Statistics of China and other collaborators several times to develop China's MRIO tables for 1997, 2002, and 2007 (Xu and Li 2008; Li et al. 2010; Li and Xu 2012). The Institute of Geographic Sciences and Natural Resources Research of the Chinese Academy of Sciences developed regional input-output tables for 30 provinces in 2007 (Liu et al. 2012).

This paper used China's MRIO tables for 1997, 2002, and 2007, which were jointly developed by the Development Research Center of the State Council of China and the National Bureau of Statistics of China (Xu and Li 2008; Li et al. 2010; Li and Xu 2012). The MRIO table for 2007 is the most recent MRIO table for China. These MRIO tables cover 30 provinces and 42 sectors for each region (no input-output tables are available for Tibet, so Tibet was not included). To facilitate the paper, the 42 sectors were combined into 13 sectors. For details, refer to Table 2 . 
Table 2 Sector classification of multi-regional input-output tables in this paper

\begin{tabular}{ll}
\hline A01 & Agriculture, forestry, animal husbandry, and fishery \\
A02 & Mining \\
A03 & Food, textiles, clothing, wood, and paper-making \\
A04 & Petrochemical \\
A05 & Building materials \\
A06 & Metal smelting and rolling and metal products \\
A07 & Other manufacturing industries \\
A08 & Electricity, gas, and water \\
A09 & Building \\
A10 & Transportation, postal service, and telecommunications \\
A11 & Commerce, accommodation, and catering \\
A12 & Finance and real estate \\
A13 & Other services \\
\hline
\end{tabular}

\section{Calculation results and analysis}

Analysis of the contribution of national exports to provincial GDP

Table 3 shows the calculation of the contribution of national exports to provincial GDP in 2007 (including direct and indirect contributions) based on the MRIO tables. In Table 3, the second column shows the GDP of each province, and the third column and fourth column show the value added for each province contributed by national exports and the province's percentage of GDP, respectively (i.e., the contribution of national exports to each province). The fifth column and sixth column exhibit each province's total exports and their percentages of GDP (i.e., the export dependence of each province).

Table 3 indicates that the national exports made significantly different contributions to each province's GDP in China. China's national exports made greater contributions to the GDP of most of the eastern provinces. The contribution was the greatest to Guangdong Province, whose value added contributed by national exports in 2007 reached 1311.8 billion yuan, accounting for 43 \% of Guangdong's GDP. National exports made smaller contributions to the GDP of the central provinces, such as Hunan and Hubei Provinces, whose value added contributed by national exports only accounted for approximately $9 \%$ of their provincial GDPs. Although the western provinces are the farthest from the export ports, the contribution of national exports to these provinces' GDP was not the smallest. The average contribution in the western provinces was greater than the contribution in the central provinces (the arithmetic mean of the percentages of the value added of the 11 western provinces contributed by national exports was $7.8 \%$, whereas that of the 6 central provinces was $7 \%$ ).

Table 3 also shows the foreign export dependence of each province. The data in Table 3 indicate that the foreign export dependence of most of the eastern provinces was relatively higher. The foreign export dependence of Guangdong Province was the highest, reaching 93 \% in 2007. To some extent, this explains why national exports made such a great contribution to the GDP of the eastern provinces. By comparing the foreign export dependence of each eastern province with the contribution of national exports to their GDP, however, we observed that the contribution of national exports to the eastern provinces' GDP was far less than their foreign export dependence. For example, the 
Table 3 Contribution of national exports to each province in 2007 (in 100 million yuan)

\begin{tabular}{|c|c|c|c|c|c|}
\hline Region & GDP & $\begin{array}{l}\text { Each province's } \\
\text { value added } \\
\text { contributed } \\
\text { by national } \\
\text { exports (VAE) }\end{array}$ & $\begin{array}{l}\text { Contribution } \\
\text { of national exports } \\
\text { to provincial GDP } \\
\text { (VAE/GDP) (\%) }\end{array}$ & $\begin{array}{l}\text { Total exports } \\
\text { of each province }\end{array}$ & $\begin{array}{l}\text { Foreign export } \\
\text { dependence } \\
\text { of each province } \\
\text { (\%) }\end{array}$ \\
\hline \multicolumn{6}{|l|}{ Eastern provinces } \\
\hline Beijing & 9579 & 2579 & 27 & 4363 & 46 \\
\hline Tianjin & 5050 & 1564 & 31 & 2248 & 45 \\
\hline Hebei & 13,778 & 2736 & 20 & 1388 & 10 \\
\hline Shanghai & 12,189 & 5143 & 42 & 11,220 & 92 \\
\hline Jiangsu & 26,508 & 9044 & 34 & 13,508 & 51 \\
\hline Zhejiang & 18,839 & 6009 & 32 & 9590 & 51 \\
\hline Fujian & 9249 & 2840 & 31 & 3829 & 41 \\
\hline Shandong & 25,575 & 6592 & 26 & 6765 & 26 \\
\hline Guangdong & 30,843 & 13,118 & 43 & 28,666 & 93 \\
\hline Hainan & 1203 & 181 & 15 & 184 & 15 \\
\hline \multicolumn{6}{|l|}{ Central provinces } \\
\hline Shanxi & 5733 & 1020 & 18 & 569 & 10 \\
\hline Anhui & 7335 & 1152 & 16 & 650 & 9 \\
\hline Jiangxi & 5500 & 542 & 10 & 408 & 7 \\
\hline Henan & 15,012 & 1806 & 12 & 679 & 5 \\
\hline Hubei & 9402 & 889 & 9 & 599 & 6 \\
\hline Hunan & 9200 & 859 & 9 & 448 & 5 \\
\hline \multicolumn{6}{|c|}{ Western provinces } \\
\hline Inner Mongolia & 6288 & 1119 & 18 & 268 & 4 \\
\hline Guangxi & 5959 & 784 & 13 & 435 & 7 \\
\hline Chongqing & 4179 & 405 & 10 & 304 & 7 \\
\hline Sichuan & 10,505 & 751 & 7 & 497 & 5 \\
\hline Guizhou & 2772 & 355 & 13 & 146 & 5 \\
\hline Yunnan & 4758 & 555 & 12 & 182 & 4 \\
\hline Shaanxi & 5575 & 987 & 18 & 386 & 7 \\
\hline Gansu & 2753 & 521 & 19 & 442 & 16 \\
\hline Qinghai & 797 & 72 & 9 & 68 & 9 \\
\hline Ningxia & 899 & 146 & 16 & 122 & 14 \\
\hline Xinjiang & 3596 & 653 & 18 & 278 & 8 \\
\hline \multicolumn{6}{|c|}{ Northeastern provinces } \\
\hline Liaoning & 11,194 & 2422 & 22 & 2466 & 22 \\
\hline Jilin & 5407 & 684 & 13 & 274 & 5 \\
\hline Heilongjiang & 7071 & 1142 & 16 & 383 & 5 \\
\hline
\end{tabular}

foreign export dependence of Guangdong Province was $93 \%$, whereas its value added contributed by national exports accounted for $43 \%$ of its GDP. There are two important reasons for this: first, a large part of China's foreign trade belongs to the processing trade (i.e., exports require the import of a large number of intermediate products), and the domestic value added rate is low. Therefore, although the foreign export dependence is higher, the percentage of the value added contributed by exports is relatively low. The economic relationships between the regions lead to high export spillover effects in the eastern provinces; in other words, the exports of these provinces require the purchase of intermediate raw materials from inland provinces, which boosts the GDPs of the inland 
provinces. This is why foreign export dependence cannot be used to measure the contribution of exports to provincial GDP. In fact, the contribution of exports to the eastern provinces' economies tends to be overestimated when using foreign export dependence.

In other regions, the foreign export dependence of the central and western provinces is significantly lower than that of eastern provinces. The foreign export dependence of the central provinces was the lowest and accounted for only $6.39 \%$. Above, we noted that the contribution of exports to the western provinces' economies was not the lowest, but was higher than the contribution of exports to the central provinces' economies. Considering that the foreign export dependence of the western region was the lowest, it can be inferred that the economic relationships between the western and eastern provinces are closer than the economic relationships between these regions and the central regions. By comparing the western provinces' foreign export dependence with their contribution to exports, we found that for the western provinces, the contribution of national exports to GDP was significantly higher than the foreign export dependence. For example, Yunnan Province's foreign export dependence was only $4 \%$ in 2007, whereas the contribution of national exports to its GDP reached $12 \%$. The contributions of national exports to the GDP of Inner Mongolia, Guangxi, Chongqing, Sichuan, Guizhou, Yunnan, Shaanxi, Gansu, Qinghai, Ningxia, and Xinjiang were substantially higher than their foreign export dependence. Therefore, for the western provinces, the contribution of exports to their economies will be underestimated when using foreign export dependence because the spillover effects of export production in other regions are not considered.

The changes in the contribution of national exports to provincial economies (Table 4) indicated that generally, the contribution of national exports to provincial economies gradually increased. The increasing trend was especially pronounced from 2002 to 2007. For example, Shanghai's value added contributed by national exports as a percentage of GDP increased from $28 \%$ in 1997 to $42 \%$ in 2007. This suggests that exports have an increasing impact on China's provincial economies, and China's provinces are gradually becoming integrated into the global market, either directly or indirectly. In addition, the data in Table 3 indicate that the foreign export dependence of the eastern provinces was generally lower than the contribution of national exports to their GDP, whereas the foreign export dependence of the central and western provinces was generally higher than the contribution of national exports to their GDP.

\section{Analysis of total spillover effect of exports}

In the previous section, we analyzed the contribution of national exports to each province's GDP. Part of the contribution was made by local exports, also known as direct contributions; the other part of the contribution was made by the exports of other provinces, known as the spillover effects of interregional exports. Figure 1 shows the direct contribution of exports to each province's economy in 2007 [i.e., the percentage of each province's value added contributed by local exports to those contributed by national exports (the vertical axis)]. As shown in Fig. 1, the contribution of the exports of the eastern provinces was high and accounted for approximately $80-90 \%$ of their total contributions. For example, the value added of Guangdong Province contributed by local exports accounted for $90 \%$ of its value added contributed by national exports in 2007 . The contribution of the exports of the central and western provinces was low, however, 
Table 4 Changes in the contribution of national exports to provincial economies

\begin{tabular}{|c|c|c|c|c|c|c|}
\hline \multirow[t]{2}{*}{ Region } & \multicolumn{3}{|c|}{$\begin{array}{l}\text { Foreign export dependence of each } \\
\text { province }(\%)\end{array}$} & \multicolumn{3}{|c|}{$\begin{array}{l}\text { Contribution of national exports } \\
\text { to the GDP of each province (\%) } \\
\text { (VAE/GDP) }\end{array}$} \\
\hline & 1997 & 2002 & 2007 & 1997 & 2002 & 2007 \\
\hline \multicolumn{7}{|l|}{ Eastern provinces } \\
\hline Beijing & 35 & 19 & 46 & 23 & 16 & 27 \\
\hline Tianjin & 36 & 49 & 45 & 24 & 28 & 31 \\
\hline Hebei & 6 & 6 & 10 & 12 & 11 & 20 \\
\hline Shanghai & 41 & 56 & 92 & 28 & 33 & 42 \\
\hline Jiangsu & 19 & 31 & 51 & 19 & 23 & 34 \\
\hline Zhejiang & 20 & 31 & 51 & 19 & 23 & 32 \\
\hline Fujian & 33 & 30 & 41 & 25 & 25 & 31 \\
\hline Shandong & 16 & 16 & 26 & 16 & 16 & 26 \\
\hline Guangdong & 91 & 68 & 93 & 43 & 35 & 43 \\
\hline Hainan & 19 & 7 & 15 & 16 & 11 & 15 \\
\hline \multicolumn{7}{|l|}{ Central provinces } \\
\hline Shanxi & 12 & 8 & 10 & 16 & 11 & 18 \\
\hline Anhui & 6 & 6 & 9 & 11 & 11 & 16 \\
\hline Jiangxi & 6 & 3 & 7 & 8 & 6 & 10 \\
\hline Henan & 4 & 3 & 5 & 7 & 6 & 12 \\
\hline Hubei & 6 & 4 & 6 & 8 & 6 & 9 \\
\hline Hunan & 5 & 4 & 5 & 8 & 6 & 9 \\
\hline \multicolumn{7}{|c|}{ Western provinces } \\
\hline Inner Mongolia & 6 & 4 & 4 & 11 & 8 & 18 \\
\hline Guangxi & 9 & 6 & 7 & 12 & 9 & 13 \\
\hline Chongqing & 4 & 5 & 7 & 9 & 8 & 10 \\
\hline Sichuan & 5 & 5 & 5 & 7 & 6 & 7 \\
\hline Guizhou & 6 & 4 & 5 & 8 & 8 & 13 \\
\hline Yunnan & 8 & 4 & 4 & 10 & 6 & 12 \\
\hline Shaanxi & 9 & 0 & 7 & 10 & 5 & 18 \\
\hline Gansu & 4 & 10 & 16 & 7 & 9 & 19 \\
\hline Qinghai & 7 & 9 & 9 & 9 & 8 & 9 \\
\hline Ningxia & 9 & 3 & 14 & 11 & 6 & 16 \\
\hline Xinjiang & 4 & 6 & 8 & 9 & 10 & 18 \\
\hline \multicolumn{7}{|c|}{ Northwestern provinces } \\
\hline Liaoning & 21 & 18 & 22 & 18 & 17 & 22 \\
\hline Jilin & 10 & 7 & 5 & 12 & 12 & 13 \\
\hline Heilongjiang & 12 & 5 & 5 & 15 & 10 & 16 \\
\hline
\end{tabular}

especially in certain western provinces that are rich in resources. For example, Shanxi, Inner Mongolia, and Shaanxi are China's main coal-producing areas and produced a total of 9.94, 9.6, and 4.63 tons of coal in 2012, respectively, ranking first, second, and third in China in terms of coal production. The value added of Shanxi, Inner Mongolia, and Shaanxi contributed by local exports accounts for only $10-20 \%$ of the value added contributed by national exports. This indicates that the contribution of exports to these provinces' GDP stems primarily from the spillover effects of interregional exports.

To show the different sources of contributions to each province's economy, the changes in the indirect contribution of exports to each province's economy in 1997, 


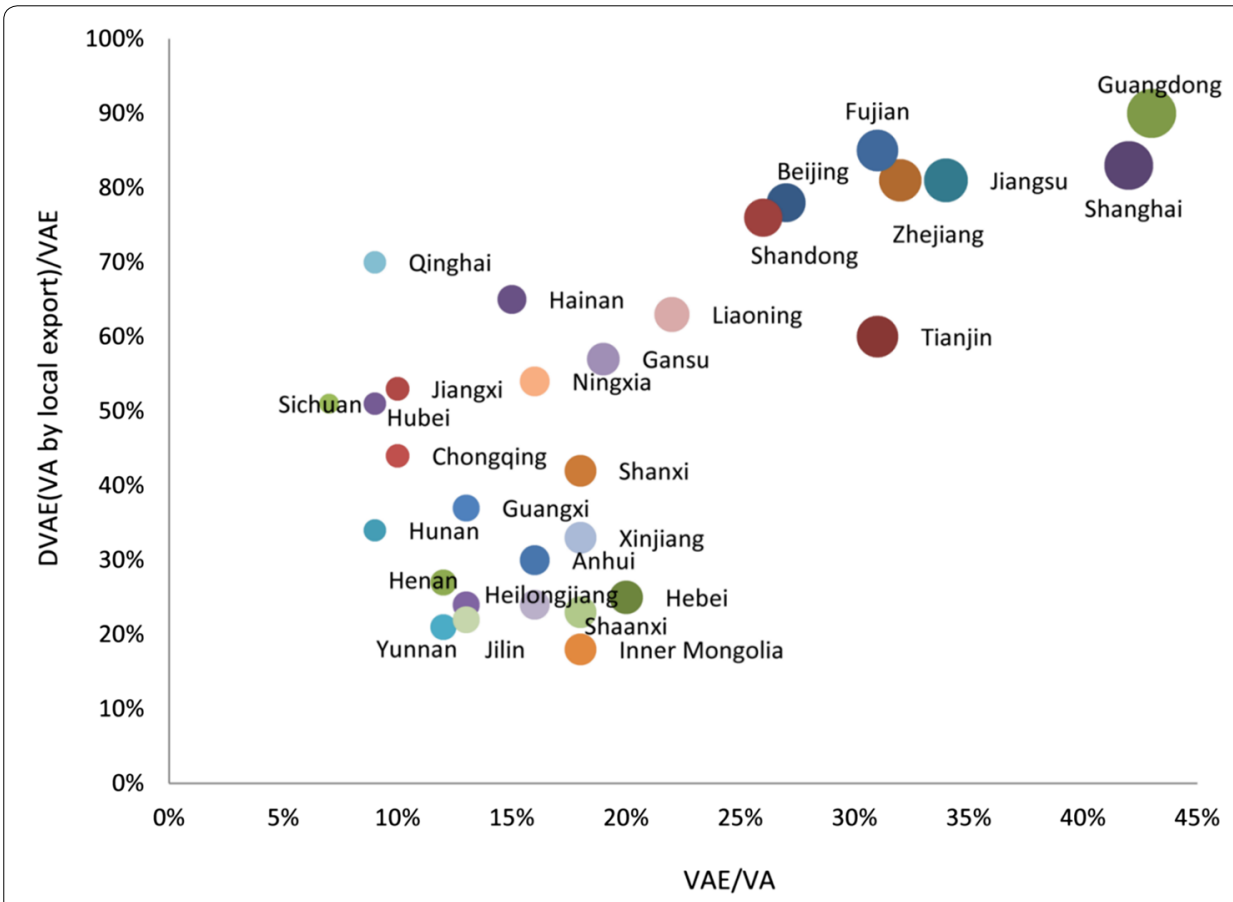

Fig. 1 Direct contribution of exports to provincial economy in 2007. Note: The vertical axis represents the percentage of each province's value added contributed by local exports compared to the percentage of the value added contributed by national exports; the horizontal axis represents the percentage of each province's value added contributed by national exports to the GDP

2002, and 2007 are listed in Table 5. Table 5 shows that each province's value added contributed indirectly by exports increased. This indicates that the level of integration of China's domestic market is improving and the economic connections between regions are strengthening. At the regional level, however, the indirect contribution of exports to the central, western, and northeastern provinces has been consistently high, whereas the indirect contribution of exports to the eastern provinces has been low. In addition, Table 4 shows that the indirect contribution of exports to the western provinces, such as Inner Mongolia, Shaanxi, Guizhou and Yunnan, increased year by year. For example, the indirect contribution of exports to Inner Mongolia increased from 60 \% in 1997 to $63 \%$ in 2002 and $82 \%$ in 2007. This indicates that exports made an increasing contribution to the western provinces' economies through the export spillover effect of other provinces [i.e., other provinces contribute to these provinces' economic growth by purchasing raw materials (or energy) from them for production and export]. Therefore, the western provinces usually act as suppliers of raw materials to other provinces. Considering that the eastern provinces' exports made a greater direct contribution, the pattern of regional economic development in China can be visualized. The eastern provinces are gradually integrated into the global industrial chain through the processing trade. Most of the western provinces do not integrate into the global industrial chain, but instead become the suppliers of raw materials for the eastern provinces. This suggests that the level of integration of China's domestic market is improving and the economic connections between provinces are tightening; however, this leads to a greater regional development gap (Liu and Zhang 2008). 
Table 5 Changes in the indirect contribution of exports to provincial economies

\begin{tabular}{|c|c|c|c|c|c|c|}
\hline \multirow[t]{2}{*}{ Region } & \multicolumn{3}{|c|}{$\begin{array}{l}\text { Each province's value added contributed } \\
\text { by the exports of other provinces ( } 100 \\
\text { million yuan) }\end{array}$} & \multicolumn{3}{|c|}{$\begin{array}{l}\text { Indirect contribution of exports } \\
\text { to each province's economy }{ }^{a}(\%)\end{array}$} \\
\hline & 1997 & 2002 & 2007 & 1997 & 2002 & 2007 \\
\hline \multicolumn{7}{|l|}{ Eastern provinces } \\
\hline Beijing & 63 & 241 & 578 & 16 & 34 & 22 \\
\hline Tianjin & 83 & 133 & 622 & 28 & 22 & 40 \\
\hline Hebei & 324 & 442 & 2055 & 68 & 67 & 75 \\
\hline Shanghai & 183 & 262 & 869 & 20 & 14 & 17 \\
\hline Jiangsu & 468 & 333 & 1718 & 38 & 14 & 19 \\
\hline Zhejiang & 186 & 423 & 1137 & 22 & 23 & 19 \\
\hline Fujian & 114 & 96 & 416 & 15 & 9 & 15 \\
\hline Shandong & 281 & 380 & 1607 & 26 & 24 & 24 \\
\hline Guangdong & 159 & 265 & 1291 & 5 & 6 & 10 \\
\hline Hainan & 21 & 36 & 63 & 27 & 55 & 35 \\
\hline \multicolumn{7}{|l|}{ Central provinces } \\
\hline Shanxi & 107 & 94 & 596 & 47 & 36 & 58 \\
\hline Anhui & 192 & 292 & 809 & 65 & 72 & 70 \\
\hline Jiangxi & 66 & 88 & 256 & 48 & 60 & 47 \\
\hline Henan & 160 & 192 & 1316 & 56 & 56 & 73 \\
\hline Hubei & 133 & 125 & 436 & 47 & 50 & 49 \\
\hline Hunan & 119 & 145 & 564 & 52 & 56 & 66 \\
\hline \multicolumn{7}{|l|}{ Western provinces } \\
\hline Inner Mongolia & 69 & 100 & 919 & 60 & 63 & 82 \\
\hline Guangxi & 115 & 126 & 491 & 48 & 57 & 63 \\
\hline Chongqing & 81 & 116 & 225 & 68 & 70 & 56 \\
\hline Sichuan & 101 & 112 & 365 & 43 & 40 & 49 \\
\hline Guizhou & 34 & 62 & 269 & 53 & 64 & 76 \\
\hline Yunnan & 68 & 83 & 436 & 41 & 56 & 79 \\
\hline Shaanxi & 56 & 109 & 761 & 42 & 67 & 77 \\
\hline Gansu & 36 & 40 & 223 & 64 & 35 & 43 \\
\hline Qinghai & 10 & 9 & 22 & 56 & 33 & 30 \\
\hline Ningxia & 12 & 16 & 68 & 51 & 68 & 46 \\
\hline Xinjiang & 67 & 96 & 435 & 68 & 58 & 67 \\
\hline \multicolumn{7}{|c|}{ Northeastern provinces } \\
\hline Liaoning & 129 & 228 & 888 & 20 & 25 & 37 \\
\hline Jilin & 68 & 186 & 532 & 40 & 67 & 78 \\
\hline Heilongjiang & 176 & 224 & 863 & 44 & 59 & 76 \\
\hline
\end{tabular}

${ }^{a}$ The ratio of the province's total value added contributed by the exports of other provinces to the value added contributed by national exports

A province will not only be affected by the export spillover effects of other provinces but also produces a spillover effect on other provinces. Table 6 shows each province's export spillover effects on other provinces in 1997, 2002, and 2007. Based on the value added of each province contributed by the export spillover effect, the eastern provinces' export spillover effects was the greatest. In particular, Guangdong Province had the greatest export spillover effect, and the value added of other provinces contributed by their exports reached 607.8 billion yuan in 2007 . The export spillover effect of the western provinces was relatively smaller, and the value added of other provinces contributed 
Table 6 Changes in each province's export spillover effects

\begin{tabular}{|c|c|c|c|c|c|c|}
\hline \multirow[t]{2}{*}{ Region } & \multicolumn{3}{|c|}{$\begin{array}{l}\text { Value added of export spillover } \\
(100 \text { million yuan })^{\mathrm{a}}\end{array}$} & \multicolumn{3}{|c|}{ Proportion of export spillover ${ }^{\mathbf{b}}(\%)$} \\
\hline & 1997 & 2002 & 2007 & 1997 & 2002 & 2007 \\
\hline \multicolumn{7}{|l|}{ Eastern provinces } \\
\hline Beijing & 127 & 237 & 1211 & 27 & 34 & 38 \\
\hline Tianjin & 136 & 306 & 858 & 39 & 40 & 48 \\
\hline Hebei & 77 & 115 & 562 & 33 & 34 & 45 \\
\hline Shanghai & 334 & 518 & 2234 & 31 & 24 & 34 \\
\hline Jiangsu & 340 & 495 & 2563 & 31 & 19 & 26 \\
\hline Zhejiang & 173 & 784 & 3148 & 20 & 36 & 39 \\
\hline Fujian & 174 & 185 & 868 & 22 & 16 & 26 \\
\hline Shandong & 172 & 269 & 1019 & 18 & 18 & 17 \\
\hline Guangdong & 1457 & 1430 & 6078 & 33 & 24 & 34 \\
\hline Hainan & 21 & 11 & 18 & 28 & 28 & 13 \\
\hline \multicolumn{7}{|l|}{ Central provinces } \\
\hline Shanxi & 45 & 25 & 76 & 27 & 13 & 15 \\
\hline Anhui & 53 & 69 & 240 & 34 & 38 & 41 \\
\hline Jiangxi & 21 & 21 & 90 & 22 & 27 & 24 \\
\hline Henan & 32 & 34 & 145 & 20 & 18 & 23 \\
\hline Hubei & 36 & 27 & 103 & 19 & 18 & 19 \\
\hline Hunan & 38 & 26 & 117 & 25 & 19 & 28 \\
\hline \multicolumn{7}{|l|}{ Western provinces } \\
\hline Inner Mongolia & 18 & 14 & 49 & 28 & 20 & 20 \\
\hline Guangxi & 42 & 46 & 102 & 25 & 33 & 26 \\
\hline Chongqing & 18 & 35 & 96 & 32 & 42 & 35 \\
\hline Sichuan & 27 & 35 & 79 & 16 & 17 & 17 \\
\hline Guizhou & 15 & 10 & 47 & 34 & 22 & 36 \\
\hline Yunnan & 30 & 17 & 35 & 24 & 20 & 23 \\
\hline Shaanxi & 37 & 2 & 128 & 32 & 32 & 36 \\
\hline Gansu & 10 & 38 & 101 & 33 & 33 & 25 \\
\hline Qinghai & 5 & 12 & 10 & 39 & 41 & 17 \\
\hline Ningxia & 6 & 4 & 37 & 34 & 37 & 32 \\
\hline Xinjiang & 12 & 19 & 46 & 28 & 22 & 17 \\
\hline \multicolumn{7}{|c|}{ Northeastern provinces } \\
\hline Liaoning & 122 & 175 & 596 & 19 & 20 & 28 \\
\hline Jilin & 36 & 55 & 98 & 27 & 38 & 39 \\
\hline Heilongjiang & 69 & 33 & 76 & 23 & 18 & 21 \\
\hline
\end{tabular}

by the exports of western provinces was essentially less than 10 billion yuan in 2007. This is related to the larger amount of exports from the eastern provinces and the position of each province in the industrial chain. The eastern provinces are mostly located downstream in the industrial chain, so their exports make a greater contribution; the central and western provinces are upstream in the industrial chain, so their exports make a smaller contribution.

Based on the percentage of the total value added of other provinces contributed by a province's exports to the total value added contributed by the exports (i.e., export 
spillover effect), the export spillover effect of the eastern provinces was greater. Comparing the value added of spillover effects, however, showed that the spillover effect of the eastern provinces was insignificant. The primary reason for this effect is that although the value added of other provinces contributed by the export spillover effects of the eastern provinces was greater, China's economy, especially the manufacturing industry, is concentrated in eastern provinces with strong agglomeration effects and supporting capacity. Therefore, the production of the products exported from eastern provinces is mainly completed in the local region, which contributes greatly to the eastern provinces' economies but has a smaller spillover effect on other provinces.

\section{Analysis of the export spillover effect between provinces}

Although the export spillover effect was analyzed in the previous section, the spillover effect between provinces was not clear to date. For example, it was unclear which province was most significantly affected by Guangdong Province's exports and which other provinces were affected by a specific province's export spillover effects. Therefore, further analysis was needed. Table 7 shows the three provinces that had the greatest export spillover effects on other provinces in 2007 and related data. Guangdong, Zhejiang, Jiangsu, and Shanghai in the eastern region are the main sources of export spillover effects on provinces in other regions (western, central, and northeastern) in China. Guangdong is the source of the greatest export spillover effects on nearly all other provinces. For example, the three provinces with the greatest spillover export effects on Shaanxi in 2007 were Guangdong, Zhejiang, and Jiangsu. The value added of Shaanxi contributed by these three provinces accounted for 29,12 , and $10 \%$, respectively, of the sum of the value added contributed by other provinces. The total value added of Shaanxi contributed by the three provinces reached 18.7 billion yuan.

Guangdong, Zhejiang, Jiangsu, and Shanghai became the sources of export spillover effects on China's provinces because the amount of exports of these provinces makes up a large proportion of China's total exports. These provinces are also located in the heartland of the processing industries in China. Therefore, their exports make a significant contribution to other provinces' economies.

Guangdong's exports make the greatest contribution to the value added value added of resource-intensive industries such as mining (A02) and metal smelting and rolling and metal products (A06) in the western region (Table 8). The value added of Inner Mongolia contributed by Guangdong's exports in 2007 was 25 billion yuan, of which the value added of the mining industry was 8.67 billion yuan and the value added of metal smelting and rolling and metal products was 3.99 billion yuan. This further validates the pattern of regional economic development in China identified earlier: the eastern provinces are the primary exporting areas, and the western provinces are the main suppliers of raw materials for the eastern provinces.

\section{Conclusions}

This paper developed a measurement model for the contribution of exports to the regional economies of a country based on the Chenery-Moses model. The contribution of national and provincial exports to provincial economies in China was measured using 
Table 7 Three provinces with the greatest export spillover effects in 2007

\begin{tabular}{|c|c|c|c|c|c|}
\hline \multirow{2}{*}{$\begin{array}{l}\text { Region } \\
\text { Eastern provinces }\end{array}$} & \multirow[t]{2}{*}{$\begin{array}{l}\text { Three provinces with greatest } \\
\text { export spillover effects in } 2007^{a}\end{array}$} & \multicolumn{3}{|c|}{$\begin{array}{l}\text { Contribution of the } \\
\text { three provinces } \\
\text { with the largest } \\
\text { spillover effects (\%) }\end{array}$} & \multirow[t]{2}{*}{$\begin{array}{l}\text { Value added contributed } \\
\text { by spillover effect } \\
{\text { (100 million yuan })^{c}}^{\text {con }}\end{array}$} \\
\hline & & & & & \\
\hline Beijing & Shanghai, Guangdong, Tianjin & 29 & 18 & 10 & 333 \\
\hline Tianjin & Guangdong, Beijing, Jiangsu & 28 & 12 & 12 & 327 \\
\hline Hebei & Guangdong, Zhejiang, Jiangsu & 25 & 19 & 14 & 1186 \\
\hline Shanghai & Guangdong, Jiangsu, Zhejiang & 26 & 19 & 14 & 345 \\
\hline Jiangsu & Guangdong, Zhejiang, Shanghai & 27 & 18 & 14 & 549 \\
\hline Zhejiang & Guangdong, Shanghai, Jiangsu & 37 & 13 & 12 & 551 \\
\hline Fujian & Guangdong, Jiangsu, Shanghai & 30 & 11 & 11 & 274 \\
\hline Shandong & Guangdong, Zhejiang, Jiangsu & 23 & 22 & 12 & 492 \\
\hline Guangdong & Zhejiang, Shanghai, Jiangsu & 24 & 17 & 16 & 732 \\
\hline Hainan & Guangdong, Zhejiang, Jiangsu & 47 & 17 & 12 & 1300 \\
\hline \multicolumn{6}{|l|}{ Central provinces } \\
\hline Shanxi & Guangdong, Jiangsu, Zhejiang & 40 & 18 & 13 & 802 \\
\hline Anhui & Guangdong, Jiangsu, Zhejiang & 27 & 16 & 13 & 456 \\
\hline Jiangxi & Zhejiang, Shanghai, Jiangsu & 39 & 12 & 11 & 258 \\
\hline Henan & Guangdong, Zhejiang, Jiangsu & 30 & 12 & 11 & 134 \\
\hline Hubei & Guangdong, Zhejiang, Jiangsu & 28 & 17 & 16 & 972 \\
\hline Hunan & Guangdong, Jiangsu, Zhejiang & 28 & 19 & 17 & 831 \\
\hline \multicolumn{6}{|l|}{ Western provinces } \\
\hline Inner Mongolia & Guangdong, Zhejiang, Jiangsu & 27 & 13 & 11 & 221 \\
\hline Guangxi & Guangdong, Jiangsu, Zhejiang & 34 & 11 & 10 & 312 \\
\hline Chongqing & Guangdong, Shanghai, Zhejiang & 24 & 17 & 16 & 732 \\
\hline Sichuan & Guangdong, Jiangsu, Zhejiang & 32 & 13 & 12 & 277 \\
\hline Guizhou & Guangdong, Zhejiang, Jiangsu & 27 & 12 & 11 & 32 \\
\hline Yunnan & Guangdong, Zhejiang, Jiangsu & 38 & 15 & 8 & 136 \\
\hline Shaanxi & Guangdong, Zhejiang, Jiangsu & 29 & 12 & 10 & 187 \\
\hline Gansu & Guangdong, Jiangsu, Zhejiang & 29 & 14 & 12 & 148 \\
\hline Qinghai & Guangdong, Shanghai, Jiangsu & 30 & 21 & 15 & 285 \\
\hline Ningxia & Guangdong, Shanghai, Zhejiang & 24 & 14 & 13 & 394 \\
\hline Xinjiang & Guangdong, Zhejiang, Jiangsu & 30 & 17 & 16 & 140 \\
\hline \multicolumn{6}{|c|}{ Northeastern provinces } \\
\hline Liaoning & Guangdong, Zhejiang, Jiangsu & 22 & 11 & 10 & 9 \\
\hline Jilin & Guangdong, Shanghai, Jiangsu & 22 & 13 & 10 & 31 \\
\hline Heilongjiang & Guangdong, Zhejiang, Jiangsu & 30 & 20 & 12 & 271 \\
\hline
\end{tabular}

a Three source provinces with the largest spillover effects

${ }^{b}$ The percentages of the value added contributed by the exports of the three largest provinces to the value added of the corresponding provinces contributed indirectly by exports

c Sums of the value addeds of the corresponding provinces contributed by the exports of the three provinces

China's MRIO tables for 1997, 2002, and 2007. The following conclusions and policy implications were obtained through the analysis of the measurement results.

First, national exports make significantly different contributions to provincial GDP in different regions in China. The contribution of national exports to the GDP of the eastern provinces was significantly greater than the contribution to the GDP of the provinces in other regions. The contribution of national exports to the GDP of the central and western provinces was small, but the contribution of national exports to the economies 
Table 8 Value added of different sectors of the western provinces contributed by Guangdong's exports in 2007 (in 100 million yuan)

\begin{tabular}{|c|c|c|c|c|c|c|c|c|c|c|c|}
\hline $\begin{array}{l}\text { Depart- } \\
\text { ment }\end{array}$ & $\begin{array}{l}\text { Inner } \\
\text { Mon- } \\
\text { golia }\end{array}$ & Guangxi & $\begin{array}{l}\text { Chong- } \\
\text { qing }\end{array}$ & Sichuan & Guizhou & $\begin{array}{l}\text { Yun- } \\
\text { nan }\end{array}$ & Shaanxi & Gansu & $\begin{array}{l}\text { Qing- } \\
\text { hai }\end{array}$ & Ningxia & $\begin{array}{l}\text { Xinji- } \\
\text { ang }\end{array}$ \\
\hline A01 & 20.4 & 36.0 & 5.8 & 21.2 & 4.9 & 9.2 & 17.5 & 1.8 & 0.3 & 0.5 & 14.0 \\
\hline A02 & 86.7 & 10.4 & 2.5 & 7.8 & 17.4 & 6.9 & 59.4 & 12.6 & 2.1 & 2.6 & 82.5 \\
\hline A03 & 22.3 & 21.8 & 4.0 & 11.3 & 6.1 & 25.4 & 6.9 & 0.5 & 0.1 & 0.5 & 2.3 \\
\hline $\mathrm{A} 04$ & 6.7 & 10.3 & 3.6 & 7.5 & 3.4 & 4.6 & 24.1 & 9.9 & 0.7 & 1.6 & 7.0 \\
\hline A05 & 2.3 & 1.3 & 0.5 & 0.7 & 0.5 & 0.2 & 0.9 & 0.4 & 0.0 & 0.1 & 0.2 \\
\hline A06 & 39.9 & 27.2 & 7.8 & 14.1 & 11.0 & 37.9 & 12.0 & 24.7 & 0.1 & 1.6 & 3.2 \\
\hline A07 & 1.0 & 7.8 & 38.3 & 16.2 & 3.0 & 2.6 & 16.3 & 1.7 & 0.3 & 0.9 & 0.5 \\
\hline A08 & 23.4 & 10.6 & 3.7 & 5.4 & 14.8 & 9.6 & 7.4 & 7.2 & 0.4 & 3.2 & 3.2 \\
\hline A09 & 0.2 & 0.1 & 0.2 & 0.1 & 0.1 & 0.1 & 0.6 & 0.1 & 0.0 & 0.0 & 0.1 \\
\hline A10 & 19.5 & 6.8 & 3.9 & 5.2 & 5.6 & 6.3 & 8.7 & 1.2 & 0.3 & 1.0 & 5.0 \\
\hline A11 & 16.4 & 19.3 & 10.9 & 10.4 & 5.8 & 16.9 & 19.1 & 3.9 & 0.3 & 2.0 & 8.7 \\
\hline A12 & 7.5 & 3.5 & 2.2 & 4.3 & 4.4 & 7.2 & 4.7 & 1.6 & 0.2 & 0.5 & 2.9 \\
\hline A13 & 3.8 & 1.2 & 1.6 & 1.6 & 1.8 & 2.1 & 7.4 & 1.3 & 0.1 & 0.3 & 1.8 \\
\hline Total & 250 & 156 & 85 & 106 & 79 & 129 & 185 & 67 & 5 & 15 & 131 \\
\hline
\end{tabular}

of the central and western provinces was significantly greater than the foreign export dependence. Therefore, in the current international market downturn, the eastern provinces, which occupy a higher proportion of foreign trade, must accelerate their transformation to address the negative impacts of the export slump. The central and western provinces must also make full use of their comparative advantages by undertaking an industrial transformation and improving the development environment to address the indirect impacts of the export slump.

Second, each province has a different source of contribution made by exports. The contribution made by exports to the economies of the eastern provinces stemmed mainly from the exports themselves, whereas the contributions made by export to the economies of the central and western provinces (especially the western provinces) stemmed from the export spillover effects of the eastern provinces. This indicates that the eastern provinces are more profoundly integrated into the global industrial chain through the processing trade, while most of the western provinces are not yet integrated into the global industrial chain, but have instead become the suppliers of raw materials for the eastern provinces. Therefore, the western provinces must enhance their endogenous aptitude for economic growth; improve their scientific and technical innovation capability, industrial supporting capacity, and institutional innovation; and change the intensive growth model that relies on resource outputs.

Third, Guangdong, Zhejiang, Jiangsu and Shanghai in the eastern region were the main source of export spillover effects for other provinces in China. In particular, Guangdong was the largest source of export spillover effects and made a great contribution to the value added of resource-intensive industries such as mining in the western region. Therefore, if the exports of Guangdong and the other eastern provinces decrease, other provinces will be affected. This indicates that changes in the international market and foreign trade policy will have an important impact on China's regional economy. 


\section{Authors' contributions}

SW and SL designed the research and methodology. SW and YL collected the data and compiled all the data and literature. SW finished the experiment and calculation. SW, SL and YL analyzed the results and put forward the policies. SW revised the manuscripts and approved the manuscripts. SW will responsible for the future questions from readers as the corresponding authors. All authors read and approved the final manuscript.

\section{Author details}

${ }^{1}$ School of Humanities and Economic Management, China University of Geosciences, No. 29 Xueyuan Road, Haidian District, Beijing 100083, People's Republic of China. ${ }^{2}$ Key Laboratory of Carrying Capacity Assessment for Resource and Environment, Ministry of Land and Resource, Beijing 100083, China. ${ }^{3}$ Development Research Center of State Council, Beijing 100010, China.

\section{Acknowledgements}

The authors are grateful for financial support from the National Natural Science Foundation of China under Grant Nos. 71003066 and 71133003

\section{Competing interests}

The authors declare that they have no competing interests.

Received: 25 October 2015 Accepted: 12 February 2016

Published online: 29 February 2016

\section{References}

Chen X, Cheng LK, Fung KC, Lau LJ (2004) The estimation of domestic value added and employment induced by exports: an application to chinese exports to the United States. In: Presented at the 2005 American economic association meeting, Philadelphia and working paper, Stanford University

Chenery HB (1953) Regional Analysis. In: Chenery HB, Clark PG, Pinna VC (eds) The structure and growth of the Italian economy. US Mutual Security Agency, Rome, pp 97-129

Ghirmay T (2001) Exports, investment, efficiency and economic growth in LDC: an empirical investigation. Appl Econ 6:88-116

Isard W (1951) Interregional and regional input-output analysis: a model of a space economy. Rev Econ Stat 33:318-328 Islam N (1998) Export expansion and economic growth: testing for counteraction and causality. Appl Econ 3:124-145

Koopman R, Wang Z, Wei S (2014) Tracing value-added and double counting in gross exports. Am Econ Rev 2:459-494

Li S, Xu X (2012) China's regional expansion input-output tables in 2007-development and application. Tsinghua University Press, China

Li S, Qi S, Xu Z (2010) China's regional expansion input-output tables in 2002-development and application. Tsinghua University Press, China

Liu Z, Zhang S (2008) China's regional differences and correction: from the perspective of global value chain and domestic value chain. Acad Mon 5:38-46 (China)

Liu W, Chen J, Tang Z (2012) Theories and practices of development of China's interregional input-output tables of 30 provinces/cities in 2007. China Statistics Press, China

Mattoo A, Wang Z, Wei S (2013) Trade in value added: developing new measures of cross-border trade. CEPR and World Bank, Washington DC

Moses LN (1955) The stability of interregional trading patterns and input-output analysis. Am Econ Rev 45:803-832

Pan W, Li Z (2007) Feedback and spillover effect of economic impacts between China's coastal area and inland. Econ Res 5:82-102

Shan J, Wilson K (2001) Causality between trade and tourism: empirical evidence from China. Appl Econ Lett 4:66-72

Shen $L$ (2011) How the changes of final demand affect the changes in industrial structure-an analysis of input-output tables. Econ Technol 12:45-57 (China)

Shen L, Wu Z (2004) Contribution of exports to China's GDP growth-empirical analysis based on input-output tables. Econ Res 9:102-116 (China)

Wu S, Lei Y, Li L (2015) Evaluation of the contributions of four components of gross domestic product in various regions in China. PLoS ONE 10(4):e0121594. doi:10.1371/journal.pone.0121594

Xu X, Li S (2008) Development and analysis of China's regional input-output tables in 1997. Tsinghua University Press, China

Zhang X, Hu J (1999) Behind free trade-import trade and national economic development. Int Trade Issues 4:57-62 (China) 